\title{
Prohibition of Torture and Inhuman or Degrading Treatment, in the Light of Article 3 of the European Convention on Human Rights
}

\author{
Phd. Myzafer Elezi
}

Sicurity Academy, Tirana - Albania; myzafer.elezi@gmail.com

\section{Esmeralda Ormeni}

esmeraldaormeni@yahoo.it

\author{
Doi:10.5901/ajis.2016.v5n2p111
}

\begin{abstract}
One of the main principles of the rule of law and in the core of a democracy itself are the human rights and fundamental freedoms. These freedoms, for the importance that represent in the democratic socities, are reflected in many national and international important documents. The legal mechanism that foresee the guarantee and the respect of the human rights and fundamental freedoms, is the European Court of Human Rights. In the heart of the human rights stand the right to live, free from torture, free from inhuman or humiliating tretament or punishment. Usually the human rights violations occur aganist people who are arrested, under custody, the conditions where they serve their sentence, extradiction, deportation, house and property destruction, forced displacement and discrimination. These rights are included in article 3 of the European Convention on Human Rights. It is seen that the Convention doesn't give an expressed definition what torture or inhuman treatment means, but just gives a rule of the absolut prohibition of the toruture or inhuman treatment. This stand does not constitute a forgetfulness or lapse of the Convention. The reason of this stand of the Convention is based on the fact, that intepretation of the torture or inhuman treatment should be a dinamic interpretation. The definiton whether we have to do with torture or inhuman treatment should be done based on the conditions, circumstances and evolution of these terms in time. Also the Convention foresees control instruments for the respect of human rights, from each state member.
\end{abstract}

Keywords: fundamental freedoms, human rights, torture, inhuman or humiliating treatment.

\section{Introduction}

The purpose of this paper is to address human rights and fundamental freedoms, as a universal right provided for in the laws of international character. The paper has the following objectives: identification of the guarantee instruments of the European Convention on Human Rights, the absolute nature of Article 3 of the Convention, and identification of the states obligations under Article 3 of the Convention.

The methodology used is the analysis of crime prevention of torture and inhuman and degrading treatment in view of Article 3 of the European Convention on Human Rights, as well as review of case studies related to such offenses under the Convention, to which the European Court of Human Rights is declared by judicial decision.

Human Rights and Fundamental Freedoms are a very important element of the rule of law. Without respecting them, we can not have the existence of a democratic state. Protection and respect of human rights and fundamental freedoms can not be made only through the national legislation of the states, but are needed international instruments in order to have a bigger guarantee in respecting them.

We want to emphasize that article 3 of the European Convention on Human Rights, constitutes one of the fundamental values of the democratic socities which adhere to Council of Europe, whereas by the time of its signing the European Convention on Human Rights represented a revolution in the field of the international law of the human rights. In the Albanian Constitution, article 17 gives the status of a constitutional norm to the definitions of the human rights and fundamental freedoms, foreseen in the Convention.

\section{The Guarantee Instruments of the European Convention on Human Rights}

European Convention on Human Rights has never had a purely declarative character. It is not confined to the announcement of some general principles and norms. In accordance with its implemention was created a special 
mechanism. He has recently undergone changes, but originally consisted of two bodies that had the function of: "to ensure the fulfillment of the commitments they have undertaken the contracting parties" (Article 19). These two bodies that have operated for a long time were, the European Commission of Human Rights and the European Court of Human Rights. The essence of the function of these two bodies has been, the review and settlement of disputes and complaints filed by one State to another and also by an individual to his State for the violation of the Convention norm. (Puto, Arben. (2008), Public International Law. Tirana, Albin, pg 220). The procedure has undergone through some restrictions, before it arrived at the current stage. Initially the Commission on Human Rights was authorized to take only the demands of state applications, a state versus another state. But with regards to the individual requirements of different nationality citizens, the Commission may take them only if states had previously made a declaration under article 25 of the Convention, by which the Commission accepted jurisdiction to review these claims. It was necessary even another statement, which accepted the compulsory jurisdiction of the European Court of Human Rights before this court can examine individual claims. In many cases the final instance was the Committee of Ministers (Ibrid). So from what we have mentioned above, in its origin the Convention had forseen two instruments to control the respect of human rights and fundamental freedoms under in Convention by the contracting parties. As follow we will make a more detailed analysis of these bodies.

\subsection{European Commission of Human Rights}

The commission was founded in 1954, it was consisted as many members as the number of states that had ratified the ECHR. The Committee Members were proposed by Contracting States and elected by the Committee of Ministers of the Council of Europe, for a 6-year term renewable. The criterias to be met from the members of the Commission were:

a. High moral integrity;

b. Sufficient qualification to be in the highest judicial system positions in the country;

c. Knoweledge of the national and international law;

d. Operate with their personal capacity (so, they are independant from the country they are proposed);

e. A country could not have more than one member as part of the Commission.

The Commission meets eight times a year in two-week sessions and examines issues of committees composed of three persons.

The European Commission is competent to examine the complaints related to possible violations of the provisions of the Convention from any contracting state, on the basis of the complaint that any state can do, non-governmental organization, group of people or an individual. Complaints of non-governmental organizations, group of people and individuals can be submitted to the Commission only if the party against which the appeal is addressed, states that it accepts the competence of the Commission. Commission may consider relevant case only after they have exhausted all domestic remedies. The Commission can not take into procedure a petition, if it is anonymous; if substantially is the same with the petition that the Commission has reviewed or presented any other instance of international or contains no relevant new facts; and if the petition does not comply with the provisions of the Convention or is apparent that it represents the abuse of the right of petition. (Gruda, Zejnullah, 2007, International Protection of Human Rights, Fama University, Prishtina, pg 48).

The Commission after receipt of the complaint shall endeavor to resolve the issue amicably. When the matter is settled amicably, a report is compiled and sent to:

- Stakeholder;

- Committee of Ministers;

- Secretary General of the Council of Europe.

In case the issue is not resolved amicably, the Commission based on facts and evidence, draw up a report where is determined whether we have or not a violation of the Convention. This report is submitted to the Committee of Ministers. Within 3 (three) months, the matter may be submitted to the European Court of Human Rights. With time it was seen not necessary to make structural changes to simplify procedures for reviewing claims for breach of the Convention. An important role played the Protocol no. 11. He set only a single body to review complaints, this body would be the European Court of Human Rights, by merging the Commission as the body which examined complaints.

From 1954-1998 we had two inspection bodies, for the respect of human rights and fundamental freedoms under the Convention, from membering states. With the entry into force of the Protocol no. 11 on 01 November 1998, these institutions were replaced by the European Court of Human Rights. A permanent body able to fulfill all the previous functions of the organs. 
The Reform was necessary for several reasons:

- First, it was the increasing number of applications and cases presented for review, the complexed character of these cases;

- Second, the full participation of a significant number of countries of Central and Eastern Europe which came out of totalitarian regimes;

- Third, the deepening of integration processes into the European Union, accompanied by a increasing place that human rights were taking as a paramount authority of the ideals of the Union. The purpose of the Protocol no. 11 was:

- Reconstruction of the control mechanism for respecting human rights and fundamental freedoms under the Convention and additional protocols;

- Increase the effectiveness of the protection of human rights.

\subsection{European Court of Human Rights}

European Convention of Human Rights except the Commission had provided the European Court of Human Rights as an instrument to control its compliance and additional protocols, from the contracting parties. It is necessary to make the distinguish between the European Court of Human Rights before the changes made by Protocol no. 11 and the Court created after this Protocol. The label is the same but differ from the previous body, the court today is a permanent body able to fulfill all the previous functions of the organs.

Article 1 of the Convention obliges the contracting states to provide for every citizen within their jurisdiction the rights and freedoms defined in the Convention. The European Court of Human Rights is just monitoring the actions taken by states while exercising their judicial powers. This relationship between the legal systems of the contracting states and the Court "principle of subsidiarity", where implementation of the Convention by the local authority runs parallel with European supervision, gave cause the existence of the margin of evaluation. The appreciation doctrine recognizes that in many cases trial national authorities are in a better position to decide on a particular case or matter. This is especially justified when there is a wide range of choices in terms of how an issue can be resolved. However, the margin of appreciation is applied differently depending on the value of the interest and the existence of common standards applied in many Member States where, respectively, the degree of the margin of appreciation allowed to states varies. (Council of Europe, 2013, Prohibtion of Torture, (the Manual of the Human Rights, No. 6), Tirana, Gent Grafik, pg.5).

\section{General Overview of Article 3 of the European Convention on Human Rights}

Prohibition of torture, punishment or inhuman or degrading treatment is a fundamental value of a rule of law. The importance of the prohibition of torture, punishment or inhuman or degrading treatment, is seen as an important principle in international law. Stopping the above mentioned behaviors it is provided in a number of international acts:

- Universal Declaration of Human Rights of 1948;

- Four Geneva Conventions of 1949;

- International Pact of the United Nations for the Civil and Political Rights of 1966

- Convention against Torture and other Cruel Inhuman or Degrading Treatment or Punishment, United Nations in 1987;

- The Rome Statute of the International Criminal Court, 1998;

- European Convention for the Prevention of Torture and Inhuman or Degrading Punishment March 1, 2002.

Despite the disappointing compliance by which credible reports indicate that torture continued to occur throughout the world, the prohibition on torture is not only a prohibition contained in the Convention, but is also part of the international customary law and is considered to be jus cogens ${ }^{5}$.

In addition to introducing the international law prohibition of torture, punishment or inhuman or degrading treatment is provided in most of the legislation of many countries.

The European Court of Human Rights has said more than once that: "Article 3 enshrines one of the most fundamental values of democratic society." The Article 3 of the Convention states that: "No one can undergo torture or inhuman or degrading treatment or punishment". (Council of Europe, 2013, Prohibition of Torture, (The mnual of Human Rights, No. 6), Tirana, Gent Grafik, pg 8).

With fifteen words, Article 3 of the Convention is one of the shortest provisions in the Convention. However, this short article should not be underestimated because the content is very important. Local authorities have difficulty in some 
cases to meet this provision, once they realize what is meant by respecting and implementing it. (European Convention of the Humna Rights).

The range of issues poses a number of points to be discussed about the scope of Article 3 as follows:

- Firstly, there is a wide range of specific behaviors and acts that may violate Article 3.

- $\quad$ The potential breaker of Article 3 and the consequences of their acts.

- Whether specific behavior or acts actually have resulted in a violation of Article 3 to be determined on the basis of subjective and objective tests.

- Article 3 contains both substantive aspects as well as procedural ones, such as the obligation to investigate prima facie allegations of torture perpetrated other inhumane treatments.

- Article 3 may be prejudiced by the deliberate abuses by negligence or passivity also in specific steps or failure to provide adequate standards of care.

- Article 3 imposes obligations as well as positive obligations, "namely an obligation not to perform a certain action, and the obligation to take positive steps to ensure respect for individuals of their rights and to protect them by mistreatment. (Council of Europe, 2013, Prohibition of Torture, (The mnual of Human Rights, No. 6), Tirana, Gent Grafik, pg 9).

Article 3 despite the fact that is one of the shortest provisions of the Convention as noted above, is very important. To analyze what is necessary to determine its components: Torture; Inhuman treatment; Humiliating treatment; and inhuman or degrading punishment.

\section{The Absolut Character of Article 3 of the European Convention on Human Rights}

The absolute character of Article 3 (prohibition to torture, punishment or inhuman and degrading treatment) must be related to Article 15 of the European Convention on Human Rights. Article 15 states:

a. In case of war or other public emergency threatening the life of the nation, any high contracting party may take measures to avoid the responsibility envisaged by the Convention, but only to the extent that the situation demands and conditions that these measures not be in contradiction with other obligations arising from international law.

b. the above provision does not authorize any derogation from Article 2, except in respect of deaths resulting lawful acts of war, or from Articles 3,4 (paragraph 1) and 7.

c. each contracting party exercising this right of derogation, holds fully inform the Secretary General of the Council of Europe of the measures taken and the reasons that have caused them. Also it must inform the Secretary General of the date on which such measures cease to operate and the provisions of the Convention are fully implemented anew. European Convention of the Humna Rights).

The rights protected by Article 3 of the Convention directly related to personal integrity and human dignity of the individual. Free from torture, inhuman or degrading punishment and degrading treatment are of paramount right. They are intolerable under Article 15 of the Convention. (Gomien, Donna. Short Guidance of the European Convention on Human Rights, Strasburg, 2005, pg.183).

If we look carefully Article 15, paragraph 2, the Convention prohibits in absolute terms torture and inhuman or degrading treatment, regardless of the victim's behavior. Court on a number of issues stated that torture, inhuman or degrading treatment is inexcusable in any conditions and circumstances, whether in the fight against organized crime or terrorism. In addition to Article 3 has absolute character and Article 2 (right to life), except when the removal of life is carried out lawfully. Also has absolute character and paragraph 1, Article 4, which prohibits slavery and servitude, while Article 7 prohibits punishment without law.

Unlike most of the positions of some materials to the Convention and the Protocols No. 1 and 4, Article 3 does not provide for exceptions or derogations under Article 15, paragraph 2 of him can not be degraded, even in cases of a situation public emergency threatening the life of the nation. The absolute prohibition of torture, inhuman and degrading treatment under the Convention, shows that art is one of the fundamental values of democratic societies that are part of the Council of Europe.

\section{The Tasks that Arises for States Based on Article 3 of the Convention}

Article 3 of the European Convention of Human Rights is of fundamental importance in a democratic society. Countries that have ratified the Convention undertake to provide for individuals within their jurisdiction are not subjected to torture, 
inhuman or degrading treatment. This obligation is not limited simply to the institutional framework, but case law has in fact an extension of the notion of extending the obligation of states in the relationship between individuals.

- With a negative obligation of the state under Article 3 of the Convention will understand: "States that are part of the ECHR, have the duty within their jurisdiction to protect individuals from torture, penalties and inhuman or degrading treatment of persons wearing with state power. In short, the negative obligation would mean that countries should not exercise self torture, punishment and inhuman or degrading treatment ". (Report state individual).

- With a positive obligation of the state under Article 3 of the ECHR would understand: "States that are part of the ECHR, have the duty within their jurisdiction to protect individuals from torture, punishments or inhuman or degrading treatment, that exercised by private persons. In short, the state must take all measures that the individual should not be subjected to torture, inhuman or degrading treatment by private persons ". (Report individual - individual).

The purpose of the provisions that prohibit torture, punishments or inhuman or degrading treatment is to protect the dignity and physical and mental integrity of the individual. Therefore, it is incumbent upon every State party to these international agreements, provide protection through legislation and other measures that may be considered necessary against the acts prohibited by international acts, "Whether caused by people acting in an official capacity, outside capacity such official or private capacity". (Anastasi, Aurela, 2009, Compared Constitute Law, Tirana, Dajti 2000, pg 142).

a. Concrete cases where the state has infringed the negative obligation under Article 3 of the Convention (Rivas vs France dated 01.04.2004). (Bianku, Ledi, 2007, Jurisprudence of the e Strasburgh Court, Tirana, EDLORA).

18-year-old Giovanni Rivas was arrested after a suspected robbery. During interrogation by the police officer he was hit kicked in the back, causing injuries that required surgery. Court despite the fact that the applicant's treatment was inhuman and degrading, pointed out: "When a person is in custody, the state assumes the obligation to ensure his welfare. This principle applies even if the detainee is a minor and has not been suspicious. "Court stressed a very important assumption that "any damage suffered during police custody, the state automatically loaded and belongs to the burden of proof to prove that the damage caused was proportionate response to the situation".

b. Specific cases where the state has violated a positive obligation under Article 3 of the Convention ( $Z$ and Others vs UK (Application no. 293392/95), 10 May 2001). (Anastasi, Aurela, 2009, Compared Constitute Law, Tirana, Dajti 2000, pg 144-146).

Seekers, four siblings. Z a girl born in 1982, A a boy born in 1984, B a boy born in 1986 and C a girl born in 1988. All four are British nationals. In October 1987, the family doctor recommended that you addressed social services due to concerns posed by children, including the fact that there was evidence that Mr. steal food. For four and a half years following the social services monitored the family and provided various forms of support for parents. During this period however, the problems continued. In October 1989, while he was investigating a robbery case, police found the children's rooms were in poor condition and mattresses urinate. In March 1990 it was reported that $Z \mathrm{f}$ A search for food in garbage bins in a school. In September 1990 it was reported that A and B had burns on his face. In a number of cases became known that children in their rooms closed where smelled rotten. Finally on June 10, 1992 children were placed in temporary care institution at the request of their mother, which said that if they would continue to be left in the care of her she would beat me. Psychology visiting children found that 3 adults expose serious emotional disturbance and noted that this was the worst case of neglect and emotional abuse that she had seen in his career.

Appointed lawyer for the applicant began procedures against local authorities claiming damages as a result of negligence shown by the authorities, which had failed to provide proper care of children and to take measures to protect them. At the conclusion of proceedings in the House of Lords researchers claim was not accepted.

The European Court of Human Rights held that: "Article 3 enshrines one of the most fundamental values of a democratic society, prohibiting in absolute terms torture or treatment or inhuman and degrading treatment, countries that have ratified the European Convention of Human Rights should, therefore, take all measures that individuals within their jurisdiction are not subjected to inhuman or degrading treatment, including such ill-treatment cases are made by private individuals in positions. These measures should provide effective protection, in particular against children and other disadvantaged and include taking reasonable measures to prevent abuses to which the authorities were aware or had the opportunity to have knowledge ". 


\section{Conclusions}

European Convention of Human Rights constituted a revolution in the field of international law on human rights at the time of its signing, for two reasons: first, there is no optional character, but mandatory for contracting states, differing from the Universal Declaration of Human Rights; and secondly, it provides instruments for the control of respect for the Convention and additional protocols by states parties.

Article 17 of the Constitution of the Republic of Albania gives the status of a constitutional norm, the limitations of human rights and fundamental freedoms under the Convention.

The Convention provides control instruments for compliance by the states parties. At first there were two bodies, the European Commission of Human Rights and the European Court of Human Rights. Later on the basis of Protocol 11, we merge the two bodies into one, only then the new created court would consider the issues presented by the parties to increase its efficiency.

Article 3 of the European Convention on Human Rights prohibits the torture, punishments or inhuman or degrading treatment, without giving a definition on these terms. This is done intentionally to the fact that the determination of whether we are dealing with torture, punishment or inhuman or degrading treatment will be based on the conditions and circumstances, and on the basis of the evolution in time of these terms.

The European Court of Human Rights has emphasized that there are many violations of article 3, occur to persons; arrested, detained or imprisoned, conditions of detention, extradition, expulsion, destruction of homes and property, forced displacement and discrimination.

The rights protected by Article 3 of the Convention directly related to personal integrity and human dignity of the individual. Freedom from torture, punishment and inhuman or degrading treatment are of paramount importance. They are intolerable under Article 15 of the Convention. Article 3 of the European Convention on Human Rights and its absolute nature can not be derogated. The absolute prohibition of torture, punishment or inhuman or degrading treatment under the Convention shows that article is one of the fundamental values of democratic societies that are part of the Council of Europe.

For countries that are part of the European Convention on Human Rights derives the obligation (positive and negative) to guarantee every individual that is within its jurisdiction not to be subjected to torture, punishment and inhuman or degrading treatment, whether by persons who are public authority, or by private persons.

Against Albania there were some issues, where is alleged violation of Article 3 of the Convention. In two cases (Grori vs Albania and Dybeku vs Albania), in its decision the Court found the claim of the parties based on violation of Article 3 of the Albanian state. In two other cases decided by the Court (Alimuçaj vs Albania and Rrapo vs Albania), the party claims are unfounded, and there is no violation of Article 3 of the Convention.

Internal legislation of the Republic of Albania is in full compliance with international treaties and in particular with the European Convention on Human Rights, the prohibition of torture, punishment or inhuman or degrading treatment, guarantees every person within its jurisdiction

\section{References}

The Constitute of the Republic of Albania, Tirana, 1998.

European Convention on Human Rights

Puto, Arben. Public Internation Law. Tirana. Albin, 2008.

Gruda, Zejnullah. International Protection of Human Rights. Fama Universitety, Pristine, 2007.

Council of Europe. Prohibition of Torture, (Manual of the Human Rights, No. 6). Tirana, 2013.

Gomien, Donna. Short Guidance of the European Convention on Human Rights, Strasburg, 2005.

Anastasi, Aurela. (2009). Compared Constitute Law. Tirana. Dajti 2000.

Bianku, Ledi. (2007). Jurisprudence of the e Strasburgh Court. Tirana. EDLORA. 